\title{
Supported Biofilms on Carbon-Oxide Composites for Nitrate Reduction in Agricultural Waste Water
}

\author{
M. Isidora Bautista-Toledo, Francisco J. Maldonado-Hódar * $\mathbb{D}$, Sergio Morales-Torres (D) \\ and Luisa M. Pastrana-Martínez (D)
}

Citation: Bautista-Toledo, M.I.;

Maldonado-Hódar, F.J.;

Morales-Torres, S.; Pastrana-Martínez,

L.M. Supported Biofilms on

Carbon-Oxide Composites for

Nitrate Reduction in Agricultural

Waste Water. Molecules 2021, 26, 2987.

https://doi.org/10.3390/

molecules26102987

Academic Editors: Ines Matos,

Maria Bernardo and Elena

Perez Mayoral

Received: 13 April 2021

Accepted: 13 May 2021

Published: 18 May 2021

Publisher's Note: MDPI stays neutral with regard to jurisdictional claims in published maps and institutional affiliations.

Copyright: (c) 2021 by the authors. Licensee MDPI, Basel, Switzerland. This article is an open access article distributed under the terms and conditions of the Creative Commons Attribution (CC BY) license (https:// creativecommons.org/licenses/by/ $4.0 /)$.
Department of Inorganic Chemistry, Faculty of Sciences, University of Granada, Avda, Fuente Nueva s/n, 18071 Granada, Spain; bautista@ugr.es (M.I.B.-T.); semoto@ugr.es (S.M.-T.); lpastrana@ugr.es (L.M.P.-M.)

* Correspondence: fjmaldon@ugr.es; Tel.: +34-(958)-240-444

\begin{abstract}
Escherichia coli colonies were grown on different supports for the removal of nitrates from water. A carbon material and different commercial metal oxides, such as $\mathrm{SiO}_{2}, \mathrm{TiO}_{2}$ and $\mathrm{Al}_{2} \mathrm{O}_{3}$, and their corresponding carbon-metal oxide composites were studied. The physicochemical properties were analyzed by different techniques and the results were correlated with their performance in the denitrification process. Developed biofilms effectively adhere to the supports and always reach the complete reduction of nitrates to gaseous products. Nevertheless, faster processes occur when the biofilm is supported on mesoporous and non-acid materials (carbon and silica).
\end{abstract}

Keywords: biofilms; carbon-oxide composites; Escherichia coli; Vibrio fischeri; denitrification; water treatment

\section{Introduction}

Water pollution, involving both organic and inorganic pollutants, is a major concern in different areas worldwide. The concentration and nature of pollutants are essentially related to human activities such as residence, industry, agriculture, etc. The concentrations of many different organic products, including emerging and recalcitrant drugs, personal care products (PCPs) and dyes from textile industries, are progressively increasing in water resources. A large variety of experimental procedures based on advanced oxidation processes (AOPs), biological treatments, membrane separation or adsorption procedures, or even, their combinations, have been developed to try to remove or mineralize these organic pollutants [1-4]. Mineralization is always desirable, avoiding the formation of residues, sludge and intermediate organic compounds, which can be even more dangerous than the original pollutants. Similarly, the pollution of water by inorganic compounds, such as heavy metals from mining or nitrates and/or phosphates mainly from agricultural activities, causes not only different alterations on human health, but also additional problems such as the eutrophication of lakes and water reservoirs $[5,6]$.

Among others, nitrates in groundwater are typically associated with intensive agricultural environments using large amounts of fertilizers and can produce many diseases, including gastric cancer [7]. In addition, nitrates are very soluble and stable, and easily drain through the soil, flowing with the groundwater and accumulating in water reservoirs. On such a basis, the concentration of nitrates and derivative nitrites was limited to $50 \mathrm{mg} \mathrm{L}^{-1}$ and $10 \mathrm{mg} \mathrm{L}^{-1}$, respectively [8]. The reduction of nitrates is today an interesting research field that uses catalytic processes, adsorption, membrane separation or ion exchange [9]. In the case of membrane-driven separation processes, the main drawback is associated with the expensive and concentrated brines generated that should be treated separately [10]. The biodegradation of nitrates by anaerobic bacteria is an interesting alternative [11]; this technology can be combined for the production of electric energy in microbial fuel cell [12]. 
Independent of the decontamination approach, it is clear that the characteristics of materials used as catalysts, adsorbents, membranes or bacteria supports should be progressively improved in order to increase their performance in the corresponding process. Researchers have focused on the optimization of different materials to be used as bacteria supports for nitrate reduction. Thus, the nature and morphology of these supports largely influenced the bioreactors or constructed wetlands for water treatments $[13,14]$. Materials with very different properties and compositions were studied as bacteria supports, in particular, zeolites [15,16], fly ash [17], metal oxides [18,19], wood [20], microalgae [21] or activated carbons (ACs) [22]. ACs are typically used for water treatment due to their non-toxic character, low price and mainly, the easy fitting of their porous and chemical properties [23].

However, a large number of novel carbon materials (i.e., graphene, carbon nanotubes, fullerenes, etc.) have emerged with better performance in water treatment processes [24,25]. Among them, carbon gels offer the same facilities of large porosity and controllable surface chemistry, but also additional advantages such as a total purity, homogeneity or the possibility to be prepared with optimized composition, nanostructure, shape or dimension $[26,27]$. Our research group previously reported the performance of inorganic metal oxides, zeolites and carbon coatings [22,28] as Escherichia coli (E. coli) bacteria supports for water denitrification. In the case of inorganic metal oxides and zeolitic materials, it was detected that the bacterial activity of denitrification decreased with the increasing acidity of the zeolitic support, leading to a marked delay in intermediate nitrite degradation. However, bacteria growth was favored by enhancing the acid character of the films, when using pure carbon xerogels obtained from a low carbonization degree [29]. In previous works, it was also previously detected that the performance of ACs as bacteria supports depended on the presence of inorganic impurities and large macropores [22].

Therefore, the nature and physicochemical properties of the supports have a significant effect on the development of bacteria colonies and finally, on their activity for the removal of inorganic pollutants. The aim of this study was to establish and elucidate the relationships between the properties and activity of the respective materials. Thus, a series of carbonmetal oxide $\left(\mathrm{C} / \mathrm{SiO}_{2}, \mathrm{C} / \mathrm{Al}_{2} \mathrm{O}_{3}\right.$ or $\left.\mathrm{C} / \mathrm{TiO}_{2}\right)$ composites were prepared and compared with pure carbon gels or commercial metal oxides, in order to establish the influence of the nature of inorganic phases. The physicochemical properties of these supports were analyzed and correlated with their ability to develop E. coli biofilms on their surface. The performance of these bacteria colonies was assessed in the reduction of both nitrates and nitrites in simulated agricultural wastewater; the synergistic effect between carbon and inorganic phases was also analyzed.

\section{Results and Discussion}

Preliminary experiments carried out in the absence of bacteria pointed out that nitrate adsorption or degradation by the supports do not occur, regardless of the material used, with the nitrate concentration remaining stable and the formation of nitrites or other degradation by-products not being detected. Therefore, the decay in nitrate concentration observed after immobilizing the biofilms on the supports is only due to the bacterial activity during the reduction process.

Figure 1a shows the biofilm's performance in the removal of nitrates when supported on pure carbon (i.e., $\mathrm{M} 500$ ) and metal oxide phases (i.e., $\mathrm{Al}_{2} \mathrm{O}_{3}, \mathrm{SiO}_{2}$ and $\mathrm{TiO}_{2}$ ). Under these experimental conditions, bacteria breathe using nitrates or nitrites as terminal electron acceptors, with denitrification occurring through the transformation of nitrates from contaminated waters to gaseous products. The reduction of nitrates by bacteria occurs following a four-step process [28,30]: microorganisms reduce nitrates $\left(\mathrm{NO}_{3}{ }^{-}\right)$progressively to nitrites $\left(\mathrm{NO}_{2}{ }^{-}\right)$, nitric oxide $(\mathrm{NO})$, nitrous oxide $\left(\mathrm{N}_{2} \mathrm{O}\right)$, and finally, to nitrogen gas $\left(\mathrm{N}_{2}\right)$. In our case, analysis of the gases was not performed, following only the evolution of the main species in the solution, i.e., $\mathrm{NO}_{3}{ }^{-}$and $\mathrm{NO}_{2}{ }^{-}$. Thus, the formation and degradation of the intermediate nitrite on the different biofilms were also analyzed and compared 
in Figure 1b. In general, E. coli colonies are able to totally mineralize the initial $\mathrm{NO}_{3}{ }^{-}$ concentration (Figure 1a). The intermediate $\mathrm{NO}_{2}{ }^{-}$progressively appears in the solution, as the $\mathrm{NO}_{3}{ }^{-}$molecules are reduced, and finally, they are also completely removed (Figure $1 \mathrm{~b}$ ).
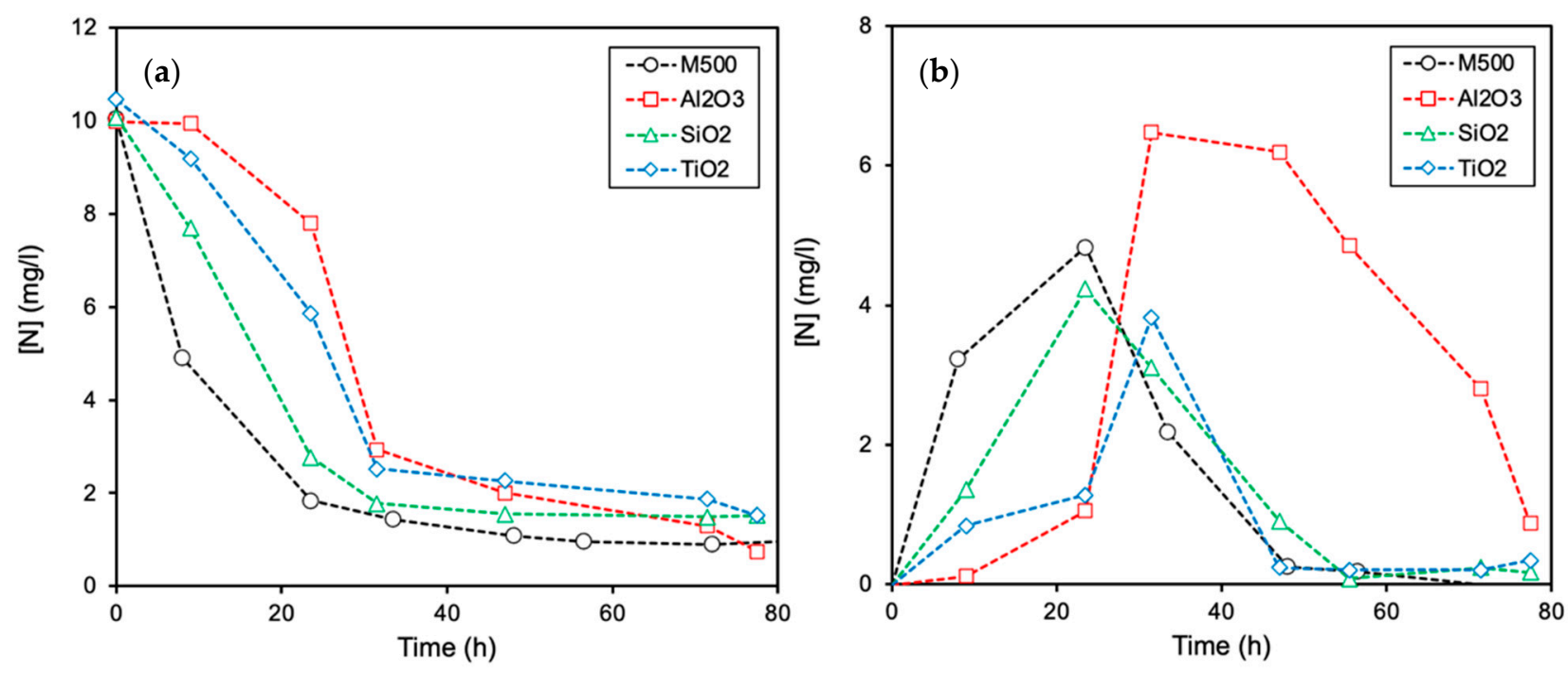

Figure 1. Denitrification activity obtained by E. coli colonies deposited on a carbon material (M500) and commercial metal oxides: (a) removal of nitrates and (b) formation and reduction of nitrites. Data are given as total nitrogen concentration.

At a glance, it is pointed out that the biofilms formed on a carbon phase (M500) are more active than those obtained on inorganic oxides. The reduction of both $\mathrm{NO}_{3}{ }^{-}$ and $\mathrm{NO}_{2}{ }^{-}$concentrations is faster in the trend: $\mathrm{Al}_{2} \mathrm{O}_{3}<\mathrm{TiO}_{2}<\mathrm{SiO}_{2}<\mathrm{M} 500$. This is an important finding, taking into account that $\mathrm{ACs}$ are typically used in wastewater treatment plants (WWTPs), produced from different origins/treatments and, therefore, contain different ash (inorganic) content and nature, which can influence their performance. On such a basis, a series of pure carbon-metal oxide composites were prepared in order to elucidate the role of the typical inorganic components on the denitrification process.

The performance of the biofilms supported on the composites regarding their pure phases is compared in Figure 2. As with the case of pure phases, both nitrates and intermediate nitrites are completely removed regardless the material tested, but bacteria supported on the carbon-metal composites present an intermediate performance between the pure carbon and the corresponding metal oxide phase. The reduction processes are progressively slower for composites containing $\mathrm{C} / \mathrm{SiO}_{2}$, followed by $\mathrm{C} / \mathrm{TiO}_{2}$ and finally, $\mathrm{C} / \mathrm{Al}_{2} \mathrm{O}_{3}$. Thus, the bacterial activity follows the same tendency previously observed by using pure metal oxides (Figure 1). The concentration of intermediate $\mathrm{NO}_{2}{ }^{-}$typically decreases after total $\mathrm{NO}_{3}{ }^{-}$reduction is achieved (Figure $2 \mathrm{~b}$ ), indicating a preferential reduction for the $\mathrm{NO}_{3}{ }^{-}$species.

The morphology of the supported biofilms was analyzed by SEM (Figure 3). In general, the formation of well-adhered E. coli colonies was achieved on all the support surfaces. An important factor that could provide additional information about the environment of the biofilm is the secretion of extracellular polymeric substances (EPS). The formation of EPS involves different mechanisms and is influenced by different factors, such as the type of substrate, the nutrient content or the external conditions [31]. In fact, it was suggested that bacteria would excrete more EPS under unfavorable conditions. 

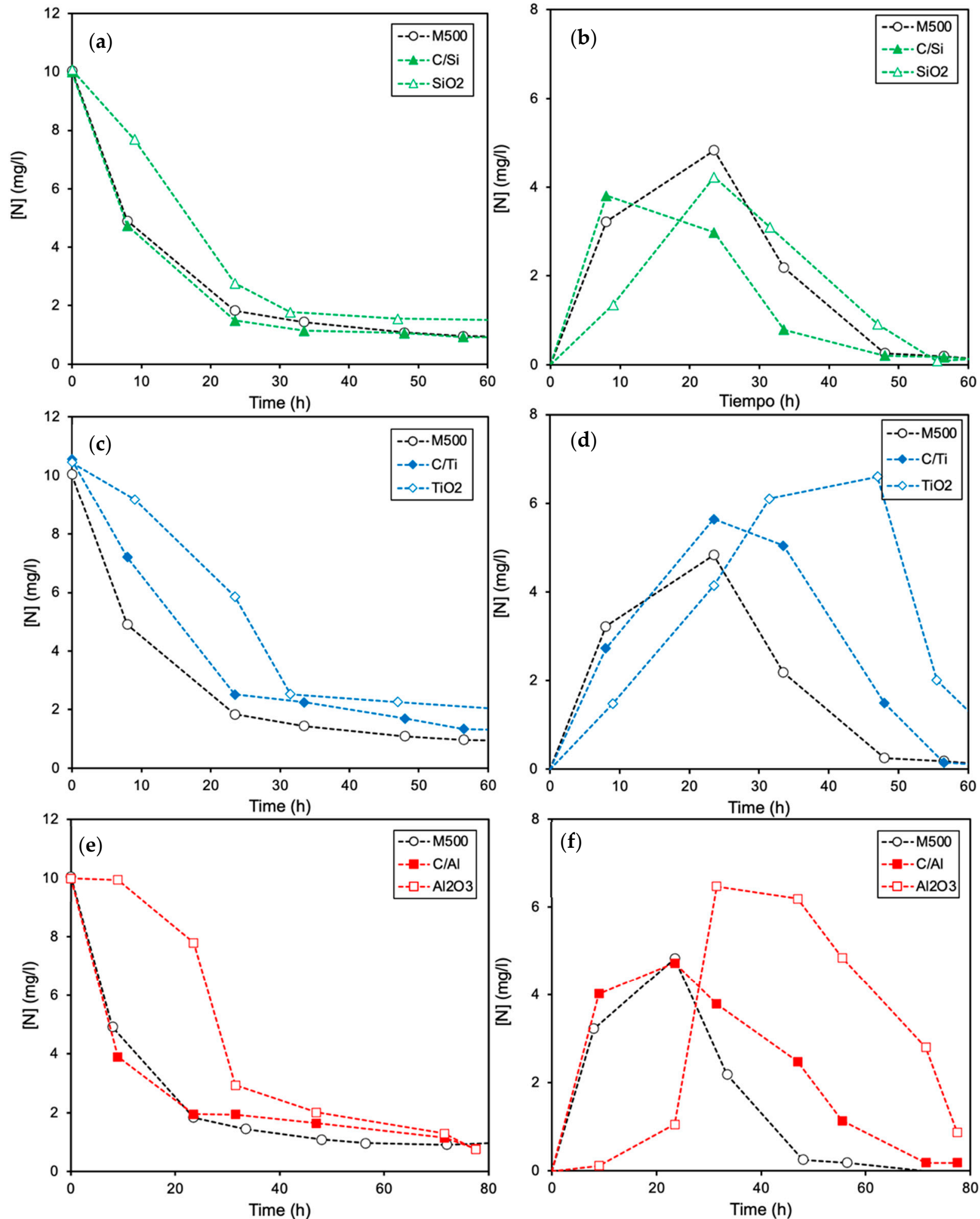

Figure 2. Comparison of the denitrification activity obtained by E. coli colonies deposited on carbon-metal oxide composites and their corresponding pure phases: $(\mathbf{a}, \mathbf{c}, \mathbf{e})$ removal of nitrates and $(\mathbf{b}, \mathbf{d}, \mathbf{f})$ formation and reduction of nitrites. Data are given as total nitrogen concentration. 


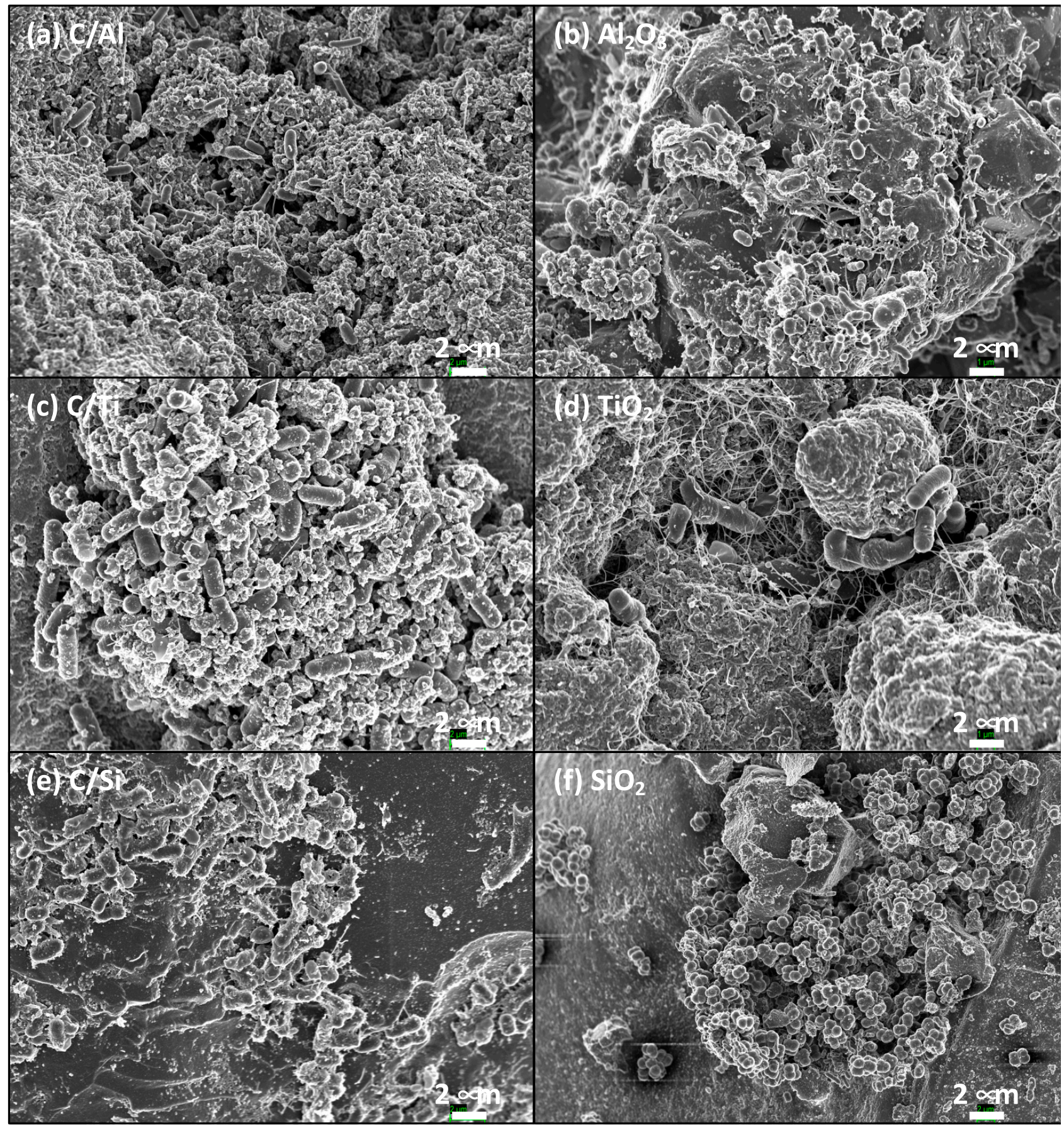

Figure 3. SEM analysis of the biofilms supported on carbon-metal oxide composites (a,c,e), regarding their corresponding pure oxides (b,d,f): (a) $\mathrm{C} / \mathrm{Al}_{2} \mathrm{O}_{3}$ vs. (b) $\mathrm{Al}_{2} \mathrm{O}_{3} ;$ (c) $\mathrm{C} / \mathrm{TiO}_{2}$ vs. (d) $\mathrm{TiO}_{2}$; and (e) $\mathrm{C} / \mathrm{SiO}_{2}$ vs. (f) $\mathrm{SiO}_{2}$.

The formation of EPS strongly influences the performance of the biofilm in wastewater treatment, in particular the mass transfer and fouling of the membranes used for water treatments [31]. In addition, the EPS structure contains many different functional groups (e.g., carboxylic acid, phenol, hydroxyl, etc.), which induce changes in the interactions with the substances (pollutants) present in water. For instance, EPS determine the nature of the aggregates during the flocculation process when used multivalent metals, as $\mathrm{Al}^{3+}$ [32], and enhance the adsorption capacity of species in solution as heavy metals [33] or organic compounds [34,35]. 
In our case, the formation of EPS seems to be favored when used pure inorganic supports (Figure 3b,d,f), in particular for pure $\mathrm{Al}_{2} \mathrm{O}_{3}$ and $\mathrm{TiO}_{2}$ as bacteria supports, regarding their corresponding composites (Figure $3 \mathrm{a}, \mathrm{c}, \mathrm{e}$ ). Since the denitrification experiments were carried out under the same experimental conditions, only by changing the bacteria support, it seems that the presence of carbon in the composites clearly reduces the EPS formation, which could suggest a more "friendly" interaction between the bacteria and support. Nevertheless, thermophilic bacteria simultaneously accumulate EPS during the nitrate reduction [36], with a positive correlation between the EPS production and the nitrate removal efficiency.

This different interaction between supports and bacteria can be correlated with the toxicity obtained for the materials. Thus, the toxicity of the supports was measured based on the inhibition degree achieved using the photoluminescent Vibrio fischeri bacteria; the results are summarized in Table 1 . The toxicity of the pure supports increases in the sense $\mathrm{M} 500 \approx \mathrm{SiO}_{2}<\mathrm{TiO}_{2}<\mathrm{Al}_{2} \mathrm{O}_{3}$, and the same trend is also observed for the corresponding composites, the pure carbon M500 being the least toxic material. The presence of carbon in the composites allows the toxicity of supports to decrease regarding their pure oxides, with the exception of $\mathrm{C} / \mathrm{SiO}_{2}$, whose toxicity $\left(\mathrm{I}_{15}=8.4 \%\right)$ presents the same order as carbon and silica phases $\left(\mathrm{I}_{15}=7.1 \%\right.$, Table 1$)$. It is noteworthy that the toxicity trend determined for the materials follows the same order in denitrification activity, previously pointed out in Figures 1 and 2.

Table 1. Toxicity determined according to ISO 11348-2:2007 for all materials used as bacteria supports.

\begin{tabular}{cccccccc}
\hline Toxicity & $\mathbf{M 5 0 0}$ & $\mathbf{S i O}_{2}$ & $\mathbf{T i O}_{2}$ & $\mathbf{A l}_{\mathbf{2}} \mathbf{O}_{3}$ & $\mathbf{S i O}_{2} / \mathrm{C}$ & $\mathbf{T i O}_{2} / \mathbf{C}$ & $\mathbf{A l}_{2} \mathbf{O}_{3} / \mathbf{C}$ \\
\hline $\mathrm{I}_{15}(\%)$ & 7.1 & 7.1 & 25.4 & 46.0 & 8.4 & 19.7 & 39.5 \\
$\mathrm{I}_{30}(\%)$ & 10.4 & 11.8 & 26.6 & 46.6 & 9.4 & 26.5 & 38.7 \\
\hline
\end{tabular}

$\mathrm{I}_{\mathrm{X}}(\%)=$ Intensity after a 15 - or $30-$ min exposure period.

Taking into account the previous results, an exhaustive characterization of the samples was carried out in order to identify the physicochemical properties of the supports influencing the activity of the biofilms in the anaerobic denitrification process. The textural and acidic-basic characteristics of the pure supports are summarized in Table 2. Textural characteristics are obtained from analysis of the $\mathrm{N}_{2}$-adsorption isotherms. The total pore volume $\left(\mathrm{V}_{\mathrm{T}}\right)$ was considered as the volume of $\mathrm{N}_{2}$ adsorbed at $\mathrm{P} / \mathrm{P}_{0}=0.95$, and the mesopore volume $\left(\mathrm{V}_{\text {meso }}\right)$ from the difference between $\mathrm{V}_{\mathrm{T}}$ and the volume of $\mathrm{N}_{2}$ adsorbed at $\mathrm{P} / \mathrm{P}_{0}=0.40\left(\mathrm{~V}_{\text {micro }}\right)$, following the Gurvich rule. The pure carbon material presents a more developed porosity than the metal oxide supports, including larger volumes of micro$\left(\mathrm{V}_{\text {micro }}\right)$ and mesopores $\left(\mathrm{V}_{\text {meso }}\right)$, and consequently, a higher apparent surface area $\left(\mathrm{S}_{\mathrm{BET}}\right)$. The micro-mesoporosity of the pure phases used as bacteria supports decreased in the sense: $\mathrm{M} 500>\mathrm{SiO}_{2}>\mathrm{TiO}_{2}>\mathrm{Al}_{2} \mathrm{O}_{3}$. However, the surface acidity of the supports presents the contrary tendency, thus alumina was the most acidic and least porous sample used, while both carbon and silica phases present high mesopore volumes and practically, a neutral character. Therefore, the performance of E. coli biofilms on pure materials (Figure 1) could be favored by increasing the porosity and/or decreasing the acidity of the supports.

The composition, acidity ( $\mathrm{pHpzc}$ ) and textural characteristics of the carbon-metal oxide composites are summarized in Table 3. All the composites present a similar metal oxide content (around $45 \pm 3 \%$ ) determined by weighing the ash content obtained after burning a sample fraction. A more exhaustive textural characterization by combining $\mathrm{CO}_{2}$ adsorption and mercury porosimetry experiments was performed for composites due to the complexity of the samples and looking for additional relationships. The determination of macroporosity and large mesopores, poorly analyzed by $\mathrm{N}_{2}$ adsorption, becomes important, since the size of bacteria is at the micrometer scale (Figure 3), while the adsorption capacity of the pollutants is related with the narrowest microporosity (micropore diameter $<0.7$ $\mathrm{nm}$, not accessible to $\mathrm{N}_{2}$ at $-196{ }^{\circ} \mathrm{C}$ and determined with $\mathrm{CO}_{2}$ at $0{ }^{\circ} \mathrm{C}$ ). This microporosity 
range $\left(\mathrm{V}_{\mathrm{CO} 2}\right)$ is negligible in pure inorganic oxides, but is favored with the incorporation of the carbon phase in the corresponding composites. Thus, the micropore volume and the corresponding micropore surface area $\left(\mathrm{S}_{\mathrm{CO} 2}\right)$ decrease regarding the pure carbon phase, but show similar values between the composites, taking into account that the metal oxide content was comparable.

Table 2. Textural characteristics and point of zero charge $\left(\mathrm{pH}_{\mathrm{PZC}}\right)$ of pure materials used as E. coli supports.

\begin{tabular}{ccccccc}
\hline Support & $\mathbf{p H}$ PZC & $\begin{array}{c}\mathrm{S}_{\text {BET }} \\
\left(\mathbf{m}^{\mathbf{2}} \mathbf{g}^{-\mathbf{1}}\right)\end{array}$ & $\begin{array}{c}\mathbf{V}_{\text {micro }} \\
\left(\mathbf{c m}^{\mathbf{3}} \mathbf{g}^{-\mathbf{1}}\right)\end{array}$ & $\begin{array}{c}\mathbf{V}_{\text {meso }} \\
\left(\mathbf{c m}^{\mathbf{3}} \mathbf{g}^{-\mathbf{1}}\right)\end{array}$ & $\begin{array}{c}\mathbf{V}_{\text {total }} \\
\left(\mathbf{c m}^{\mathbf{3}} \mathbf{g}^{-\mathbf{1}}\right)\end{array}$ & $\begin{array}{c}\mathbf{L}_{\mathbf{0}} \mathbf{N}_{\mathbf{2}} \\
(\mathbf{n m})\end{array}$ \\
\hline $\mathrm{M} 500$ & 6.3 & 611 & 0.285 & 1.035 & 1.320 & 1.63 \\
\hline $\mathrm{SiO}_{2}$ & 7.1 & 241 & 0.094 & 0.889 & 0.983 & 1.78 \\
\hline $\mathrm{TiO}_{2}$ & 4.7 & 116 & 0.047 & 0.446 & 0.493 & 1.89 \\
\hline $\mathrm{Al}_{2} \mathrm{O}_{3}$ & 4.3 & 121 & 0.047 & 0.197 & 0.244 & 1.61 \\
\hline
\end{tabular}

Results obtained from $\mathrm{N}_{2}$ adsorption isotherms: $\mathrm{S}_{\mathrm{BET}}=$ apparent surface area; $\mathrm{V}_{\text {micro }}=$ micropore volume; $\mathrm{V}_{\text {meso }}$ = mesopore volume; $\mathrm{V}_{\text {total }}=$ total pore volume; $\mathrm{L}_{0} \mathrm{~N}_{2}=$ mean micropore width accessible to $\mathrm{N}_{2}$ at $-196^{\circ} \mathrm{C}$.

Table 3. Textural characteristics and $\mathrm{pH}$ PZC of $\mathrm{M} 500$ and the carbon-metal oxide composites used as E. Coli supports.

\begin{tabular}{cccccccrr}
\hline Sample & Metal (\%) & $\mathbf{p H}$ & $\begin{array}{c}\mathbf{V}_{\mathrm{CO} 2} \\
\left(\mathbf{c m}^{\mathbf{3}} \mathbf{g}^{-\mathbf{1}}\right)\end{array}$ & $\begin{array}{c}\mathbf{V}_{\text {meso }} \\
\left(\mathbf{c m}^{\mathbf{3}} \mathbf{g}^{-\mathbf{1}}\right)\end{array}$ & $\begin{array}{c}\mathbf{V}_{\text {macro }} \\
\left(\mathbf{c m}^{\mathbf{3}} \mathbf{g}^{-\mathbf{1}}\right)\end{array}$ & $\begin{array}{c}\rho_{\mathbf{p}} \\
\left(\mathbf{g ~ c m}^{-3}\right)\end{array}$ & $\begin{array}{c}\mathbf{S}_{\mathbf{e x t}} \\
\left(\mathbf{m}^{\mathbf{2}} \mathbf{g}^{-\mathbf{1}}\right)\end{array}$ & $\begin{array}{c}\mathbf{S}_{\mathrm{CO} 2} \\
\left(\mathbf{m}^{\mathbf{2}} \mathbf{g}^{-\mathbf{1}}\right)\end{array}$ \\
\hline $\mathrm{M} 500$ & -- & 6.3 & 0.171 & 0.613 & 0.000 & 0.76 & 185 & 513 \\
$\mathrm{C} / \mathrm{SiO}_{2}$ & 42.0 & 6.0 & 0.154 & 0.033 & 0.070 & 1.24 & 15 & 407 \\
$\mathrm{C} / \mathrm{TiO}_{2}$ & 49.0 & 6.7 & 0.145 & 0.000 & 0.249 & 1.02 & 12 & 382 \\
$\mathrm{C} / \mathrm{Al}_{2} \mathrm{O}_{3}$ & 47.0 & 7.3 & 0.160 & 0.265 & 0.799 & 0.58 & 60 & 421 \\
\hline
\end{tabular}

Metal = metal oxide content $(\mathrm{wt} \%) ; \mathrm{V}_{\mathrm{CO} 2}=$ micropore volume determined from $\mathrm{CO}_{2}$ isotherms; $\mathrm{V}_{\text {meso }}=$ mesopore volume; $\mathrm{V}_{\text {macro }}=$ macropore volume; $\rho_{\mathrm{p}}=$ bulk density; $\mathrm{S}_{\mathrm{ext}}=$ external surface area; $\mathrm{SCO}_{2}=$ micropores surface area.

The pore size distribution (PSD) determined by mercury porosimetry is plotted in Figure 4 , clearly showing a developed macroporosity for $\mathrm{C} / \mathrm{Al}_{2} \mathrm{O}_{3}$ regarding the other composites, which also corroborates its significant reduction in density $\left(\rho_{\mathrm{p}}\right.$, Table 3$)$. The volumes of large mesopores $\left(\mathrm{V}_{\text {meso }}\right)$ and macropores $\left(\mathrm{V}_{\text {macro }}\right)$ for $\mathrm{C} / \mathrm{Al}_{2} \mathrm{O}_{3}$ were higher than those for the other composites (Table 3). These results clearly pointed out that the external porosity of the samples is not the limiting factor in the activity of supported biofilms, since bacteria supported on $\mathrm{C} / \mathrm{Al}_{2} \mathrm{O}_{3}$ presented the worst denitrification activity (Figure 2), while well-adhered colonies were observed in all cases (Figure 3).

Concerning the acidity of the supports, it is noteworthy that the $\mathrm{pH}_{\mathrm{pzc}}$ of the composites increased regarding the corresponding pure oxides (Table 3 vs. Table 2). This acidity decrease is due to the chemical transformations underwent by both organic and inorganic phases of the samples during the carbonization. The acidic chemical groups are evolved as gases (i.e., $\mathrm{CO}_{\mathrm{x}}, \mathrm{H}_{2} \mathrm{O}$ ) according to their thermal stability and the interactions between the metallic phase and the organic matrix. The carbonization process was simulated by thermogravimetric analysis (TG/DTG) and the results are shown in Figure 5a. The DTG profile obtained for the carbonization of pure organic polymers (result not shown for clarity) presents three main peaks centered at around $200{ }^{\circ} \mathrm{C}, 350^{\circ} \mathrm{C}$ and $550{ }^{\circ} \mathrm{C}$, associated with the loss of unreacted products, the breakage of $\mathrm{C}-\mathrm{O}$ and finally, the reorganization of $\mathrm{C}-\mathrm{C}$ and $\mathrm{C}-\mathrm{H}$ bonds $[37,38]$. The temperature of these DTG peaks in the composites significantly changes between them, indicating different organic polymer-oxide precursor linkages. The marked DTG peaks located at around $320^{\circ} \mathrm{C}$ for $\mathrm{C} / \mathrm{Al}_{2} \mathrm{O}_{3}$ are worth noting, which could suggest a larger loss of oxygenated surface groups. All composites do not present any significant weight loss from $800^{\circ} \mathrm{C}$, indicating that the main transformations occur at lower temperatures. The intimal interaction between carbon and oxide fractions was also pointed out by X-ray diffraction (XRD) (Figure 5b), with no diffraction peaks being observed that denote the presence of crystalline phases corresponding to the metallic 
phases, except a small peak at $44.5^{\circ}$ in sample $\mathrm{C} / \mathrm{Al}_{2} \mathrm{O}_{3}$ that indicates the incipient crystallization of $\mathrm{Al}_{2} \mathrm{O}_{3}$. In other words, the organic phase prevents the crystalline growth of the inorganic phases, even after heat treatment.

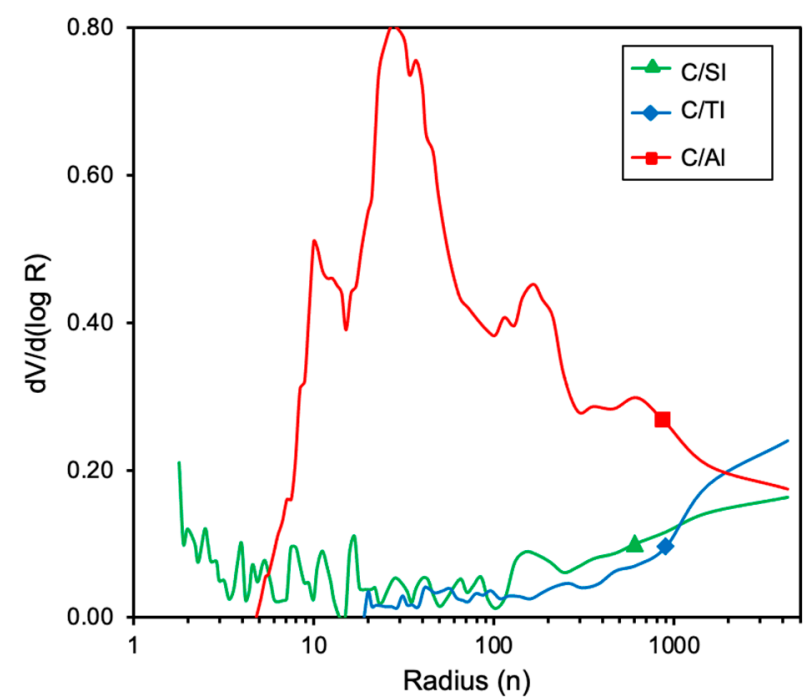

Figure 4. Meso- and macropore size distribution of the carbon-metal oxide composites determined by mercury porosimetry.
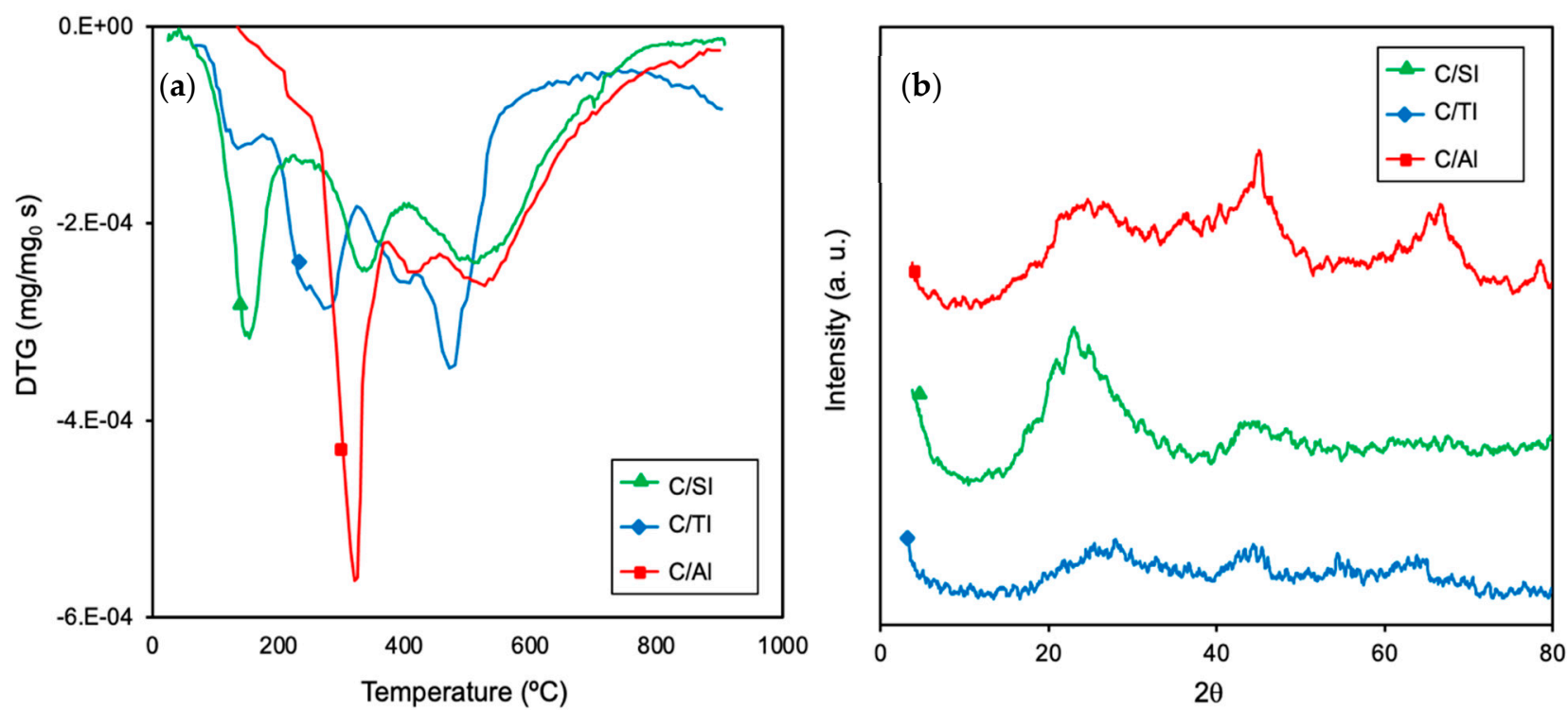

Figure 5. (a) Differential thermogravimetric (DTG) profiles obtained for the composites during the carbonization in $\mathrm{N}_{2}$ flow at $10{ }^{\circ} \mathrm{C} \mathrm{min}^{-1}$. (b) X-ray diffraction (XRD) patterns obtained for the composites.

Thus, porosity is always large enough, and in spite of the different PSD of the supports, well-adhered colonies of bacteria were observed by SEM. Nevertheless, the performance of these colonies seems to be related with the acidity of the samples. With increasing acidity, specifically the Brönsted acidity predominant on the alumina, the support becomes negatively charged in the buffered $(\mathrm{pH}=7)$ solutions, modifying the interactions with the Gram-negative E. coli bacteria, increasing the EPS segregation and decreasing the $\mathrm{NO}_{3}{ }^{-}$ and more specifically, the $\mathrm{NO}_{2}{ }^{-}$reduction.

The development of E. coli biofilms on the surface of ACs was studied in previous works [39]. The adsorption of bacteria on ACs modified their surface characteristics, reducing the volume of pores and the $\mathrm{pH}$ of the point of zero charge. It was also showed [22] that the macropore volume of granular ACs (GACs) allows bacteria growth during the 
denitrification process, while the presence of $\mathrm{Cd}(\mathrm{II})$ and $\mathrm{Cr}(\mathrm{VI})$ in the solution negatively affected the denitrification process kinetics. Nevertheless, electron donor chemicals can also be used to favor nitrate reduction [40]. More recently, it was also demonstrated that $E$. coli biofilms depend on the nature and morphology of the carbon used as the support; activated carbon cloths were a superior adsorbent of E. coli compared to GACs, and the presence of bacteria on the carbon materials increased the adsorption of pollutants (bisphenol) between $24 \%$ and $33 \%$ [41]. Using carbon xerogel films cured by microwave treatments as E. coli supports [29], it was observed that low carbonization degree and/or more acidic $\mathrm{pH}$ of point of zero charge favor bacteria growth. Nevertheless, when E. coli biofilms are supported on alkali or alkali earth exchanged zeolites [28], the acidity of the support clearly retards the reduction of nitrates and, more specifically, nitrite reduction. Others carbon forms also favor the performance of denitrification. The use of micrographite particles demonstrated an increase in abundance of the denitrifying bacteria Paracoccus in sludge (not supported), increasing its denitrifying capacity [42]. These results pointed out the importance of the environment on the biofilm's performance, determined either by the characteristics of the supports or by the presence of other substances in the solution. The different carbon forms available and the versatility of these materials to fit their physicochemical properties, probably also combined with the use of electron donor substances, are interesting routes for the reduction of nitrates in wastewaters.

\section{Materials and Methods}

The performance of different materials as bacteria supports was examined. In particular, a pure carbon gel (sample M500) and carbon-metal oxide composites (C/Si, C/ Al and $\mathrm{C} / \mathrm{Ti}$ ) were synthesized by the method developed by Pekala and later, adapted in our laboratories $[37,43,44]$. A starting solution was prepared by dissolving appropriate amounts of resorcinol (R) and formaldehyde (F) (carbon precursors) in water in a molar ratio of $\mathrm{R} / \mathrm{F}=1 / 2$ (Sample $\mathrm{M}$ ). This solution was heated up to $50{ }^{\circ} \mathrm{C}$ under vigorous stirring and then, in the case of composites, the corresponding metal alkoxide was dropped at this temperature into the reactor in a resorcinol/alkoxide molar ratio equal to unity. The metal alkoxides used during the synthesis were tetraethyl orthosilicate (TEOS), aluminum isopropoxide (ALPR) and tetrabutyl orthotitanate (TBTi) for the preparation of $\mathrm{C} / \mathrm{Si}, \mathrm{C} / \mathrm{Al}$ and $\mathrm{C} / \mathrm{Ti}$ composites, respectively. The gel formed was redispersed by stirring, aged for $4 \mathrm{~h}$, recovered by filtration, exchanged with acetone and finally, dried for 1 day at $80^{\circ} \mathrm{C}$ and 3 days at $110^{\circ} \mathrm{C}$. The pyrolysis of the organic gels was carried out in a tubular furnace using a $\mathrm{N}_{2}$ flow of $100 \mathrm{~cm}^{3} \mathrm{~min}^{-1}$, by heating up to $500{ }^{\circ} \mathrm{C}$ (sample M500) or $900{ }^{\circ} \mathrm{C}$ (composites) with a heating rate of $5^{\circ} \mathrm{C} \mathrm{min}^{-1}$, and a soaking time of $1.5 \mathrm{~h}$. Commercial metal oxides, i.e., $\mathrm{SiO}_{2}, \mathrm{Al}_{2} \mathrm{O}_{3}$ and $\mathrm{TiO}_{2}$ samples, were used as a reference and without any pretreatment. The oxide metal content of the synthetized samples was determined by burning a fraction of it at $900{ }^{\circ} \mathrm{C}$ in air.

Textural characterization of materials was performed using mercury porosimetry (Quantachrome) to determine the macro-mesoporosity (pores greater than $3.6 \mathrm{~nm}$ ) and physical adsorption of $\mathrm{CO}_{2}$ and $\mathrm{N}_{2}$ at $0{ }^{\circ} \mathrm{C}$ and $-196{ }^{\circ} \mathrm{C}$, respectively, to analyze the microporosity. The apparent surface area $\left(\mathrm{S}_{\mathrm{BET}}\right)$ was calculated applying the BET equation [45] to $\mathrm{N}_{2}$ adsorption isotherms, while Dubinin-Radushkevich and Stoeckli equations $[46,47]$ were used to determine the micropore volume $\left(\mathrm{V}_{\text {micro }}\right)$, and the mean micropore width $\left(\mathrm{L}_{0}\right)$. The micropore volume $\left(\mathrm{V}_{\mathrm{CO} 2}\right)$ and the micropore surface area $\left(\mathrm{S}_{\mathrm{CO} 2}\right)$ were also estimated from $\mathrm{CO}_{2}$ adsorption data. Mesopore volume $\left(\mathrm{V}_{\text {meso }}\right)$, macropore volume $\left(\mathrm{V}_{\text {macro }}\right)$, bulk density $\left(\rho_{\mathrm{p}}\right)$ and external surface area $\left(\mathrm{S}_{\text {ext }}\right)$ were calculated by mercury porosimetry. XRD patterns were determined with a BRUKER D8 ADVANCE diffractometer (40 kV and $40 \mathrm{~mA}$ ) using $\mathrm{Cu} \mathrm{K} \mathrm{K}_{\alpha}$ radiation. The point of zero charge $\left(\mathrm{pH}_{\mathrm{PZC}}\right)$ of the supports, which is an indication of their surface acidity, was determined by a methodology previously described elsewhere [48,49]. The morphology of supports was characterized by scanning electron microscopy (SEM) using a LEO Carl Zeiss GEMINI-1530. This technique 
was also used to study the colonization of supports by bacteria after the corresponding denitrification experiments.

Bacteria used in the experiments were Escherichia coli, ATCC ${ }^{\circledR} 25922^{\mathrm{TM}}$ strain, which was first incubated at $37^{\circ} \mathrm{C}$ using a buffered media at $\mathrm{pH} 7$ with tryptic soy broth (TSB), before being immobilized on the different supports. Bacteria were supported on the different solids, adding $1 \mathrm{~mL}$ of this suspension to $0.4 \mathrm{~g}$ of support suspended in $20 \mathrm{~mL}$ of TSB and the mixtures were shaken at $37^{\circ} \mathrm{C}$ for 3 days. Afterward, the colonized supports were filtered and washed repeatedly with sterilized distilled water.

The denitrification process of water was studied by bacteria immobilized on the different supports $(0.4 \mathrm{~g})$, which were added to $100 \mathrm{~mL}$ of a solution containing $50 \mathrm{mg} \mathrm{L}^{-1}$ of nitrate from $\mathrm{NaNO}_{3}$ and $1.3 \mathrm{~mL}$ of ethanol. The suspension was buffered at $\mathrm{pH} 7$ with an appropriate phosphate solution. The flasks used as batch bioreactors were flushed with argon atmosphere to obtain anaerobic conditions and then, placed in a thermostatic rotary shaker at $25^{\circ} \mathrm{C}$. Periodically, the concentration of nitrate was measured directly in the bioreactors with a selective electrode supplied by Mettler, and simultaneously, a small volume of solution $(1 \mathrm{~mL})$ was withdrawn for the determination of the nitrite concentration. This parameter was determined using a Hitachi model U2000 spectrophotometer at $543 \mathrm{~nm}$ after coupling diazotized sulphanilamide with N-1-naphthyl-ethylendiamine [50].

The toxicity of the inorganic solid suspensions was measured based on the inhibition of the luminescence of Vibrio fischeri marine bacteria, NRRL-B-11177. For this, a suspension of bacteria was prepared according to the European guideline ISO 11348-2:2007 and the initial luminescence was determined. The solid supports were removed from the corresponding suspensions by centrifugation to avoid interferences during the determination of the light intensity, and the water recovered was used to dilute the bacterial suspension mixed in a 1:1 ratio. Bioluminescence was measured using a LUMISTOX system after a 15-min exposure. In all measurements, the percentage inhibition (\% I) was obtained by comparing the response of a control saline solution with that obtained for the sample. Toxicity was expressed as the percentage inhibition of bacterial growth as a function of treatment time.

\section{Conclusions}

E. coli biofilms grown on different supports were active in the biodegradation of nitrates from water resources. Nitrites were observed as intermediate degradation products, but they were also progressively evolved to nitrogen gas, being totally removed from solutions. The denitrification reaction was faster for bacteria biofilms supported on carbon phases than on metal oxide supports, as follows: $\mathrm{M} 500>\mathrm{SiO}_{2}>\mathrm{TiO}_{2}>\mathrm{Al}_{2} \mathrm{O}_{3}$. This trend suggested the best performance for biofilms was on highly porous and non-acidic supports. Carbon-metal oxide composites $\left(\mathrm{C} / \mathrm{SiO}_{2}, \mathrm{C} / \mathrm{TiO}_{2}\right.$, and $\left.\mathrm{C} / \mathrm{Al}_{2} \mathrm{O}_{3}\right)$ were synthesized to determine the influence of the inorganic phase's nature on the performance of supports. Composites typically show an intermediate performance between pure phases following the same tendency. The formation of large mesopores and macropores favored well-adhered colonies. SEM analysis showed a larger EPS segregation when biofilms were supported on materials containing $\mathrm{TiO}_{2}$ and mainly $\mathrm{Al}_{2} \mathrm{O}_{3}$, denoting a less favorable environment. The worst performance of alumina was associated with the Brönsted character of their acid sites, because E. Coli are Gram-negative bacteria. With the formation of these composites, the thermoreduction of these stronger acidic sites by the organic phase during carbonization favors the performance of composites regarding pure metal oxides. Toxicity analysis with Vibrio fischeri also indicated a larger reduction in luminescence using acidic supports. Total nitrate and nitrite reduction were observed in the batch reactors; $\mathrm{NO}_{3}{ }^{-}$ reduction is faster and preferential considering the intermediate $\mathrm{NO}_{2}{ }^{-}$being progressively delayed when the acidic character of the support is increased.

Author Contributions: Conceptualization, F.J.M.-H. and M.I.B.-T.; methodology, M.I.B.-T., F.J.M.H., L.M.P.-M. and S.M.-T.; investigation, M.I.B.-T., L.M.P.-M. and S.M.-T.; writing-original draft preparation, F.J.M.-H.; writing—review and editing, M.I.B.-T., L.M.P.-M. and S.M.-T.; supervision, 
F.J.M.-H. and M.I.B.-T.; funding acquisition, L.M.P.-M., S.M.-T. and F.J.M.-H. All authors have read and agreed to the published version of the manuscript.

Funding: This work was supported by the Spanish Project ref. RTI 2018-099224-B100 funded by ERDF/Ministry of Science, Innovation and Universities-State Research Agency (Spain).

Institutional Review Board Statement: Not applicable.

Informed Consent Statement: Not applicable.

Data Availability Statement: Not applicable.

Acknowledgments: L.M.P.-M. (RYC-2016-19347) and S.M.-T. (RYC-2019-026634-I/AEI/10.13039/50110001103 acknowledge the Spanish Ministry of Economy and Competitiveness (MINECO), the State Research Agency and the European Social Found for their Ramón y Cajal research contracts. "Unidad de Excelencia Química Aplicada a Biomedicina y Medioambiente" of the University of Granada (UEQ-UGR) is gratefully acknowledged for their technical assistance.

Conflicts of Interest: The authors declare no conflict of interest.

Sample Availability: Samples of the composite materials and carbon gels are available from the authors, the rest of inorganic supports are available commercially.

\section{References}

1. Boczkaj, G.; Fernandes, A. Wastewater treatment by means of advanced oxidation processes at basic $\mathrm{pH}$ conditions: A review. Chem. Eng. J. 2017, 320, 608-633. [CrossRef]

2. Li, F.; Huang, J.; Xia, Q.; Lou, M.; Yang, B.; Tian, Q.; Liu, Y. Direct contact membrane distillation for the treatment of industrial dyeing wastewater and characteristic pollutants. Sep. Purif. Technol. 2018, 195, 83-91. [CrossRef]

3. Morales-Torres, S.; Pastrana-Martínez, L.M.; Figueiredo, J.L.; Faria, J.L.; Silva, A.M.T. Design of graphene-based TiO 2 photocatalysts-a review. Environ. Sci. Pollut. Res. 2012, 19, 3676-3687. [CrossRef] [PubMed]

4. Athanasekou, C.P.; Moustakas, N.G.; Morales-Torres, S.; Pastrana-Martínez, L.M.; Figueiredo, J.L.; Faria, J.L.; Silva, A.M.T.; Dona-Rodriguez, J.M.; Romanos, G.E.; Falaras, P. Ceramic photocatalytic membranes for water filtration under UV and visible light. Appl. Catal. B Environ. 2015, 178, 12-19. [CrossRef]

5. Kobielska, P.A.; Howarth, A.J.; Farha, O.K.; Nayak, S. Metal-organic frameworks for heavy metal removal from water. Coord. Chem. Rev. 2018, 358, 92-107. [CrossRef]

6. Sajid, M.; Nazal, M.K.; Baig, N.; Osman, A.M. Removal of heavy metals and organic pollutants from water using dendritic polymers based adsorbents: A critical review. Sep. Purif. Technol. 2018, 191, 400-423. [CrossRef]

7. Bogardi, I.; Kuzelka, R.D.; Ennenga, W. Nitrate Contamination: Exposure, Consequence, and Control; Springer: Berlin/Heidelberg, Germany, 2013; Volume 30.

8. World-Health-Organization. Guidelines for Drinking-Water Quality, 4th ed.; World Health Organization (WHO): Geneva, Switzerland, 2017; p. 520.

9. Granger, P.; Troncéa, S.; Dacquin, J.P.; Trentesaux, M.; Parvulescu, V.I. Support-induced effect on the catalytic properties of Pd particles in water denitrification: Impact of surface and structural features of mesoporous ceria-zirconia support. Appl. Catal. $B$ Environ. 2018, 224, 648-659. [CrossRef]

10. Kruithof, J.C.; Koppers, H.M.M. Experiences with groundwater treatment and disposal of the eliminated substances in the Netherlands. Aqua 1989, 38, 207-216.

11. Xu, Z.; Song, L.; Dai, X.; Chai, X. PHBV polymer supported denitrification system efficiently treated high nitrate concentration wastewater: Denitrification performance, microbial community structure evolution and key denitrifying bacteria. Chemosphere 2018, 197, 96-104. [CrossRef]

12. Naga Samrat, M.V.V.; Kesava Rao, K.; Ruggeri, B.; Tommasi, T. Denitrification of water in a microbial fuel cell (MFC) using seawater bacteria. J. Clean. Prod. 2018, 178, 449-456. [CrossRef]

13. Nuhoglu, A.; Pekdemir, T.; Yildiz, E.; Keskinler, B.; Akay, G. Drinking water denitrification by a membrane bio-reactor. Water Res. 2002, 36, 1155-1166. [CrossRef]

14. Song, K.; Lee, S.-H.; Kang, H. Denitrification rates and community structure of denitrifying bacteria in newly constructed wetland. Eur. J. Soil Biol. 2011, 47, 24-29. [CrossRef]

15. Montalvo, S.; Díaz, F.; Guerrero, L.; Sánchez, E.; Borja, R. Effect of particle size and doses of zeolite addition on anaerobic digestion processes of synthetic and piggery wastes. Process Biochem. 2005, 40, 1475-1481. [CrossRef]

16. Guerrero, L.; Montalvo, S.; Huiliñir, C.; Barahona, A.; Borja, R.; Cortés, A. Simultaneous nitrification-denitrification of wastewater: Effect of zeolite as a support in sequential batch reactor with step-feed strategy. Int. J. Environ. Sci. Technol. 2016, 13, 2325-2338. [CrossRef]

17. Montalvo, S.; Cahn, I.; Borja, R.; Huiliñir, C.; Guerrero, L. Use of solid residue from thermal power plant (fly ash) for enhancing sewage sludge anaerobic digestion: Influence of fly ash particle size. Bioresour. Technol. 2017, 244, 416-422. [CrossRef] [PubMed] 
18. Chen, Y.; Su, Y.; Zheng, X.; Chen, H.; Yang, H. Alumina nanoparticles-induced effects on wastewater nitrogen and phosphorus removal after short-term and long-term exposure. Water Res. 2012, 46, 4379-4386. [CrossRef] [PubMed]

19. Kurt, M.; Dunn, I.J.; Bourne, J.R. Biological denitrification of drinking water using autotrophic organisms with $\mathrm{H}_{2}$ in a fluidizedbed biofilm reactor. Biotechnol. Bioeng. 1987, 29, 493-501. [CrossRef]

20. Yamashita, T.; Yamamoto-Ikemoto, R.; Zhu, J. Sulfate-reducing bacteria in a denitrification reactor packed with wood as a carbon source. Bioresour. Technol. 2011, 102, 2235-2241. [CrossRef] [PubMed]

21. Liu, J.; Wu, Y.; Wu, C.; Muylaert, K.; Vyverman, W.; Yu, H.-Q.; Muñoz, R.; Rittmann, B. Advanced nutrient removal from surface water by a consortium of attached microalgae and bacteria: A review. Bioresour. Technol. 2017, 241, 1127-1137. [CrossRef] [PubMed]

22. Moreno-Castilla, C.; Bautista-Toledo, I.; Ferro-García, M.A.; Rivera-Utrilla, J. Influence of support surface properties on activity of bacteria immobilised on activated carbons for water denitrification. Carbon 2003, 41, 1743-1749. [CrossRef]

23. Vivo-Vilches, J.F.; Bailón-García, E.; Pérez-Cadenas, A.F.; Carrasco-Marín, F.; Maldonado-Hódar, F.J. Tailoring activated carbons for the development of specific adsorbents of gasoline vapors. J. Hazard. Mater. 2013, 263, 533-540. [CrossRef] [PubMed]

24. Pastrana-Martínez, L.M.; Morales-Torres, S.; Likodimos, V.; Figueiredo, J.L.; Faria, J.L.; Falaras, P.; Silva, A.M.T. Advanced nanostructured photocatalysts based on reduced graphene oxide- $\mathrm{TiO}_{2}$ composites for degradation of diphenhydramine pharmaceutical and methyl orange dye. Appl. Catal. B Environ. 2012, 123-124, 241-256. [CrossRef]

25. Silva, T.L.S.; Morales-Torres, S.; Figueiredo, J.L.; Silva, A.M.T. Multi-walled carbon nanotube/PVDF blended membranes with sponge- and finger-like pores for direct contact membrane distillation. Desalination 2015, 357, 233-245. [CrossRef]

26. Morales-Torres, S.; Maldonado-Hódar, F.J.; Pérez-Cadenas, A.F.; Carrasco-Marín, F. Structural characterization of carbon xerogels: From film to monolith. Microporous Mesoporous Mater. 2012, 153, 24-29. [CrossRef]

27. Maldonado-Hodar, F.J.; Morales-Torres, S.; Ribeiro, F.; Silva, E.R.; Perez-Cadenas, A.F.; Carrasco-Marin, F.; Oliveira, F.A. Development of carbon coatings for cordierite foams: An alternative to cordierite honeycombs. Langmuir 2008, 24, 3267-3273. [CrossRef] [PubMed]

28. Bautista-Toledo, M.I.; Espinosa-Iglesias, D.; Carrasco-Marín, F.; Pérez-Cadenas, A.F.; Maldonado-Hódar, F.J. Influence of the physicochemical properties of inorganic supports on the activity of immobilized bacteria for water denitrification. J. Environ. Manag. 2015, 156, 81-88. [CrossRef] [PubMed]

29. Valverde-Sarmiento, C.; Espinosa-Iglesias, D.; Bautista-Toledo, M.I.; Álvarez-Merino, M.A.; Maldonado-Hódar, F.J.; CarrascoMarín, F.; Pérez-Cadenas, A.F. Bacteria supported on carbon films for water denitrification. Chem. Eng. J. 2015, 259, 424-429. [CrossRef]

30. Karanasios, K.A.; Vasiliadou, I.A.; Pavlou, S.; Vayenas, D.V. Hydrogenotrophic denitrification of potable water: A review. J. Hazard. Mater. 2010, 180, 20-37. [CrossRef]

31. Shi, Y.; Huang, J.; Zeng, G.; Gu, Y.; Chen, Y.; Hu, Y.; Tang, B.; Zhou, J.; Yang, Y.; Shi, L. Exploiting extracellular polymeric substances (EPS) controlling strategies for performance enhancement of biological wastewater treatments: An overview. Chemosphere 2017, 180, 396-411. [CrossRef]

32. Kończak, B.; Karcz, J.; Miksch, K. Influence of Calcium, Magnesium, and Iron Ions on Aerobic Granulation. Appl. Biochem. Biotechnol. 2014, 174, 2910-2918. [CrossRef]

33. Moon, S.-H.; Park, C.-S.; Kim, Y.-J.; Park, Y.-I. Biosorption isotherms of Pb (II) and Zn (II) on Pestan, an extracellular polysaccharide, of Pestalotiopsis sp. KCTC 8637P. Process Biochem. 2006, 41, 312-316. [CrossRef]

34. Sheng, G.-P.; Zhang, M.-L.; Yu, H.-Q. Characterization of adsorption properties of extracellular polymeric substances (EPS) extracted from sludge. Colloids Surf. B Biointerfaces 2008, 62, 83-90. [CrossRef] [PubMed]

35. Liu, A.; Ahn, I.-S.; Mansfield, C.; Lion, L.W.; Shuler, M.L.; Ghiorse, W.C. Phenanthrene desorption from soil in the presence of bacterial extracellular polymer: Observations and model predictions of dynamic beheavior. Water Res. 2001, 35, 835-843. [CrossRef]

36. Wei, Z.; Huang, S.; Zhang, Y.; Li, H.; Zhou, S. Characterization of extracellular polymeric substances produced during nitrate removal by a thermophilic bacterium Chelatococcus daeguensis TAD1 in batch cultures. RSC Adv. 2017, 7, 44265-44271. [CrossRef]

37. Moreno-Castilla, C.; Maldonado-Hódar, F.J. Synthesis and surface characteristics of silica- and alumina-carbon composite xerogels. Phys. Chem. Chem. Phys. 2000, 2, 4818-4822. [CrossRef]

38. Lin, C.; Ritter, J.A. Effect of synthesis $\mathrm{pH}$ on the structure of carbon xerogels. Carbon 1997, 35, 1271-1278. [CrossRef]

39. Rivera-Utrilla, J.; Bautista-Toledo, I.; Ferro-García, M.A.; Moreno-Castilla, C. Bioadsorption of $\mathrm{Pb}(\mathrm{II}), \mathrm{Cd}(\mathrm{II})$, and Cr(VI) on activated carbon from aqueous solutions. Carbon 2003, 41, 323-330. [CrossRef]

40. Di Capua, F.; Pirozzi, F.; Lens, P.N.L.; Esposito, G. Electron donors for autotrophic denitrification. Chem. Eng. J. 2019, 362, 922-937. [CrossRef]

41. López-Ramón, M.V.; Ocampo-Pérez, R.; Bautista-Toledo, M.I.; Rivera-Utrilla, J.; Moreno-Castilla, C.; Sánchez-Polo, M. Removal of bisphenols A and S by adsorption on activated carbon clothes enhanced by the presence of bacteria. Sci. Total Environ. 2019, 669, 767-776. [CrossRef]

42. Li, J.; Peng, Z.; Hu, R.; Gao, K.; Shen, C.; Liu, S.; Liu, R. Micro-graphite particles accelerate denitrification in biological treatment systems. Bioresour. Technol. 2020, 308, 122935. [CrossRef] [PubMed]

43. Pekala, R.W. Low Density, Resorcinol-Formaldehyde Aerogels. U.S. Patent 4,873,218, 10 October 1989. 
44. Morales-Torres, S.; Maldonado-Hódar, F.J.; Pérez-Cadenas, A.F.; Carrasco-Marín, F. Textural and mechanical characteristics of carbon aerogels synthesized by polymerization of resorcinol and formaldehyde using alkali carbonates as basification agents. Phys. Chem. Chem. Phys. 2010, 12, 10365-10372. [CrossRef] [PubMed]

45. Brunauer, S.; Emmett, P.H.; Teller, E. Adsorption of gases in multimolecular layers. J. Am. Chem. Soc. 1938, 60, 309-319. [CrossRef]

46. Stoeckli, F. Characterization of microporous carbons by adsorption and immersion techniques. In Porosity in Carbons: Characterization and Applications; Patrick, J.W., Ed.; Edward Arnold: London, UK, 1995; pp. 66-97.

47. Bansal, R.C.; Donnet, J.B.; Stoeckli, F. Active Carbon; Marcel Dekker: New York, NY, USA, 1988.

48. Leon y Leon, C.A.; Solar, J.M.; Calemma, V.; Radovic, L.R. Evidence for the protonation of basal plane sites on carbon. Carbon 1992, 30, 797-811. [CrossRef]

49. Pastrana-Martínez, L.M.; Morales-Torres, S.; Likodimos, V.; Falaras, P.; Figueiredo, J.L.; Faria, J.L.; Silva, A.M.T. Role of oxygen functionalities on the synthesis of photocatalytically active graphene- $\mathrm{TiO}_{2}$ composites. Appl. Catal. B Environ. 2014, 158-159, 329-340. [CrossRef]

50. Kesserú, P.; Kiss, I.; Bihari, Z.; Polyák, B. Investigation of the denitrification activity of immobilized Pseudomonas butanovora cells in the presence of different organic substrates. Water Res. 2002, 36, 1565-1571. [CrossRef] 